\title{
Variation of Naturally Formed Agarwood Resins in Gyrinops walla Gaertn Growing in Sri Lanka
}

\author{
W.N.H. de Alwis ${ }^{1 *}$, S.M.C.U.P. Subasinghe ${ }^{1}$, D.S. Hettiarachchi ${ }^{2}$ \\ ${ }^{I}$ Department of Forestry and Environmental Science, University of Sri Jayewardenepura, Sri Lanka \\ ${ }^{2}$ Wescorp Group of Companies, 26, Coulson Way, Canning Vale, WA, Australia \\ *hasinide26@gmail.com
}

\begin{abstract}
Agarwood is a highly fragrant and valuable resin produced in certain species of Aquilaria and Gyrinops genera of Family Thymalaeaceae. This resin is produced as a first line defense mechanism to protect the tree stem from microbial invasions. Due to the extensive use in cosmetics, medicines, religious and cultural activities, the demand for agarwood resins in Europe, Middle East and South-east Asian regions is very high. Gyrinops walla, locally known as Walla patta is the only naturally growing agarwood producing species in Sri Lanka and it is distributed in the humid lowland forests of the wet zone and intermediate zones of low elevations. The ability of producing agarwood resins in G. walla was scientifically discovered in 2012. Parallel to that, there were reports of large scale of poaching and illegal transport of this species with certain involvements of the foreign nationals.
\end{abstract}

This study was conducted to identify the variation of agarwood resin contents of G. walla trees growing under different climatic and geographical conditions in Sri Lanka and to identify the relationship of resin contents with tree growth parameters. For this purpose, 64 trees growing in eight distinct areas, viz., Horawala, Kalatuwawa, Kalawana, Karandana, Maliboda, Mirigama, Neboda and Yagirala belong to wet and intermediate zones of low country were collected. Collected tissues were size reduced and the resins were collected by solvent extraction method. Colours of both resinous tissues and extracted resins were determined using a standard method. One-way ANOVA was conducted to identify the significance of resin contents among different regions and Pearson correlation was tested between resin contents and tree growth parameters.

The colour of the resinous tissues and extracted resins varied from light brown to dark brown and yellow to dark brown respectively. The highest average resin content $(4.92 \%)$ was recorded from Maliboda while the lowest $(2.19 \%)$ was recorded from Kalawana. One-way ANOVA did not report significant differences of resin contents between different locations. Significant correlations were also not found between resin contents and tree diameter and height. According to the resin content analysis of naturally growing trees, it was revealed that the best trees can be identified at Maliboda area to collect seeds for making the next generation in the plantation establishment.

Keywords: Agarwood, Gyrinops walla, solvent extraction, Sri Lanka 